\title{
PRZEPOWIADANIE SŁOWA BOŻEGO PODCZAS NABOŻEŃSTW LUDU BOŻEGO
}

DOI: http://dx.doi.org/10.12775/TiCz.2019.042

\begin{abstract}
Streszczenie. Artykuł prezentuje najpierw relację nabożeństw ludu Bożego do liturgii, podkreślając istniejące między nimi różnice oraz fakt, że nie ma między nimi żadnej konkurencji, a raczej zachodzi pożądana komplementarność. Nabożeństwa przygotowują do liturgii i pomagają w pogłębieniu jej przeżywania. Omówiona jest także specyfika przepowiadania słowa Bożego podczas nabożeństw ludu Bożego, która decyduje o tym, że przepowiadanie podczas liturgii określane jest terminem „homilia”, a przepowiadanie podczas nabożeństw ludu Bożego nazywane jest „kazaniem”. Na specyfikę tego ostatniego mają wpływ zarówno pozaliturgiczny kontekst przepowiadania, jak też rozszerzony podmiot posługi słowa, czyli osoby upoważnione do przepowiadania, a także język, który może być swobodniejszy niż język homilii.
\end{abstract}

Słowa kluczowe: przepowiadanie; słowo Boże; nabożeństwa ludowe.

Abstract. Preaching the Word of God in the Context of Popular Piety. This article first discusses the relation of popular piety to the liturgy, stressing the differences between them and the fact that there is no competition between them, but rather there

* Ks. prof. dr hab. Henryk Sławiński, homileta i pedagog. Pracownik Uniwersytetu Papieskiego Jana Pawła II w Krakowie. Redaktor naczelny kwartalnika „Polonia Sacra”. Przewodniczący Stowarzyszenia Homiletów Polskich. 
is desirable complementarity: popular piety services on one side prepare for the liturgy, and on the other they help to deepen the experience of the latter one. The specifics of the preaching the word of God in the context of popular piety determines the distinction, at least in the Polish language and practice, between "the sermon" and "the homily". The first one describes preaching in the context of popular piety, whereas the second term "the homily" is reserved for the preaching during the liturgy. The specifics of the sermon is influenced by the non-liturgical context of preaching, as well as the extended group of people that might preach, as well as the language that can be less restricted than the language of the homily.

Key words: Preaching; Word of God; Popular Piety.

\section{WPROWADZENIE}

Pobożność ludowa jest skarbem Kościoła, którego wartość nabiera na znaczeniu, gdy bez uprzedzeń podda się go refleksji naukowej. Nabożeństwa ludu Bożego nie są konkurencyjne dla liturgii, a stanowią ważne jej uzupełnienie i stwarzają znakomity kontekst do przepowiadania słowa Bożego.

Refleksja nad tym zagadnieniem przedstawiona zostanie w następujących po sobie punktach. Na początku omówiona zostanie relacja nabożeństw ludu Bożego do liturgii, a więc ich różnice i komplementarność. Następnie przeanalizujemy znaczenie głoszenia słowa Bożego podczas liturgii i nabożeństw. Po tym zaś wykrystalizowana zostanie specyfika przepowiadania podczas nabożeństw ludowych, na którą składają się zagadnienia dotyczące kontekstu, podmiotu przepowiadania i języka.

\section{NABOŻEŃSTWA LUDU BOŻEGO A LITURGIA: RÓŻNICE 1 KOMPLEMENTARNOŚĆ}

Teologia katolicka zachowuje rozróżnienie między liturgią a nabożeństwami ludu Bożego. Różnica ta nie ma charakteru alternatywnego, ale komplementarny. 


\subsection{RÓŻNICE MIĘDZY NABOŻEŃSTWAMI I LITURGIĄ}

Liturgia to święte działanie, przez które Chrystus jedyny i wieczysty Kapłan uświęca ludzkość i wraz z Kościołem, swoim mistycznym Ciałem oddaje całkowity kult publiczny Bogu Ojcu, prowadząc ludzi do pełni chwały w niebieskim Jeruzalem. „Każda celebracja liturgiczna jako działanie Chrystusa-Kapłana i Jego Ciała, czyli Kościoła, jest czynnością w najwyższym stopniu świętą, której skuteczności z tego samego tytułu i w tym samym stopniu nie posiada żadna inna czynność Kościoła" (KL 7). Oznacza to, że liturgia jest jedyną formą oddawania czci Bogu o charakterze zbawczym. Ponadto trzeba podkreślić, że celebracja liturgiczna jest szczytem, do którego prowadzą wszystkie chrześcijańskie praktyki pobożnościowe oraz źródłem, z którego owe praktyki czerpią swoją uświęcającą moc (por. KL 10). Uznanie priorytetowej roli liturgii w życiu Kościoła i poszczególnych chrześcijan nie może oznaczać w żadnym stopniu deprecjonowania pozaliturgicznych przejawów pobożności. Dyrektorium o pobożności ludowej i liturgii przestrzega, że „niebranie pod uwagę lub pomniejszanie zalet pobożności ludowej świadczy o braku odpowiedniego dowartościowania niektórych elementów kultycznych Kościoła i wydaje się wypływać raczej z uprzedzeń ideologicznych niż z nauki wiary" (DPLL 50)ํ. Pobożność ludowa posiada zatem cenne zalety i stanowi ważne uzupełnienie liturgicznych celebracji Kościoła.

Sama pobożność to modlitewne i uczuciowe oddanie, które sprawia, że „wierzący z głębi serca odpowiadają na to, czego Bóg od nich chce”2. Natomiast pobożność ludowa, według św. Tomasza ${ }^{3}$, to zewnętrzne ujawnienie pobożności, wewnętrznej relacji między wiernym a Bogiem4 Może wyrażać się w zachowaniu jednostki bądź zbiorowości ludzi.

1 Kongregacja ds. Kultu Bożego i Dyscypliny Sakramentów, Dyrektorium o pobożności ludowej i liturgii, Zasady i wskazania (17 grudnia 2001), Poznań 2003, nr 50 [Odtąd skrót DPLL]; por. J. Przybyłowski, Duszpasterskie wyzwania Dyrektorium o pobożności ludowej i liturgii, „Seminare” 20 (2004), s. 149.

${ }^{2}$ G. O’Collins, E.G. Farrugia, Leksykon pojęć teologicznych i kościelnych z indeksem angielsko-polskim, Wydawnictwo WAM, Kraków 2002, s. 133.

${ }^{3}$ STh II, IIae,q.82,a.2ad3.

4 B. Nadolski, Leksykon liturgii, Pallottinum, Poznań 2006, s. 995. 
Pobożność łączona jest z religijnością, która z kolei określana jest jako „zasadnicza postawa ludzi wobec Boga jako ich Stwórcy i Zbawiciela"5, wyrażająca się w adoracji i wielkodusznej służbie okazywanej Bogu6 . Do form pobożności ludowej zalicza się na przykład: cześć oddawaną relikwiom, nawiedzanie sanktuariów, pielgrzymki, procesje, drogę krzyżowa, Gorzkie żale, tańce religijne, różaniec, medaliki, kult świętych obrazów, całowanie ich, wieszanie krzyża w domu czy miejscu pracy, modlitwy za zmarłych, a także noszenie habitu czy sutanny ${ }^{7}$.

Wśród cech charakteryzujących pobożność ludową teolodzy wymieniają: 1. Otwarcie na transcendencję; 2. Pomoc w poszukiwaniu sensu życia; 3. Poczucie bezpieczeństwa i zbawienia; 4. Pogłębienie wzajemnych związków wspólnoty; 5. Objęcie całego człowieka i wszystkich dziedzin jego życia, zaangażowanie wszystkich zmysłów wierzącego człowieka i całego środowiska; 6. Bliskość życia; 7. Prostota w strukturze ${ }^{8}$.

Mówiąc o różnicy między pobożnością ludową a liturgią, należy podkreślić, że liturgia jest zbawczym działaniem Chrystusa i Kościoła, w którym priorytetowy jest element uświęcający, katabatyczny, a więc inicjatywa i działanie Boga. Innymi słowy, liturgia jest anamnezą - aktualizującym wspomnieniem, uobecnieniem zbawczych interwencji Boga w historii ${ }^{9}$. Element kultyczny, anabatyczny jest w liturgii odpowiedzią wierzących na Bożą inicjatywę. Natomiast w różnych formach pobożności ludowej priorytetową rolę odgrywa ludzkie zaangażowanie, które jest wyrazem doświadczenia Bożej miłości i inspiracji do działania. Choć nabożeństwa ludowe służą podtrzymywaniu i wzrostowi pobożności wierzących, to jednak nie dokonuje się w nich aktualizacja wydarzeń zbawczych. Nie można w odniesieniu do nich mówić o anamnezie.

${ }^{5}$ G. O’Collins, E.G. Farrugia, Leksykon, s. 133.

6 Tamże, s. 133.

7 Por. KKK 1674; Watykan: nowy dokument o pobożności ludowej (9.04.2002), https://ekai.pl/watykan-nowy-dokument-o-poboznosci-ludowej/ (data dostępu: 17.02.2018).

8 B. Nadolski, Leksykon, s. 999-1000; zob. tenże, Pobożność ludowa a liturgia, „Communio" 7 (1987) 6, s. 103.

9 Por. KKK, nr 1103; D. Brzeziński, Sakramentalność słowa Bożego w świetle adhortacji apostolskiej Benedykta XVI Verbum Domini, „Liturgia Sacra” 17 (2011), nr 1, s. 17. 
Zbawczy charakter liturgii, a zwłaszcza składających się na nią sakramentów, sprawia, że udział w nich jest niezbędny do „życia w Chrystusie”. Natomiast przejawy pobożności ludowej są fakultatywne i nie należy ich prezentować jakoby były obligatoryjne dla wierzących ${ }^{10}$.

Inna różnica między liturgią a pobożnością ludową polega na tym, że liturgia pozwala przeżywać misterium Chrystusa i poszczególne misteria odkupienia. W ten sposób odznacza się integralnością - wyraża pełną treść wiary chrześcijańskiej. Natomiast pobożność ludowa odznacza się fragmentarycznością, dając wyraz jakimś aspektom wiary chrześcijańskiej.

Wymienione różnice między liturgią i nabożeństwami ludowymi domagają się respektowania ich odmienności; nie należy dokonywać pomieszania nabożeństw ludowych $z$ liturgią ani tworzyć hybryd ${ }^{11}$. Trzeba zawsze pamiętać o tym, że liturgia $\mathrm{z}$ racji swojej natury znacznie przewyższa pobożność ludową ${ }^{12}$.

\subsection{KOMPLEMENTARNOŚĆ POBOŻNOŚCl LUDOWEJ l LITURGIl}

Podkreślenie różnic między liturgią i nabożeństwami ludu Bożego nie oznacza pomniejszania ich wzajemnej komplementarności. Obydwie formy kultu nie przeciwstawiają się sobie, ale się uzupełniają. Różne formy pobożności ludowej prowadzą do liturgii i z niej wyrastają, ale jej nie zastępują. Również liturgia nie eliminuje innych aprobowanych przez Kościół form wyrażania wiary chrześcijańskiej określanych mianem pobożności ludowej, która z biegiem wieków zawsze odgrywała istotną rolę w życiu, zarówno prywatnym, jak i publicznym ${ }^{13}$. Zadaniem biskupów jest czuwanie nad tym, by praktykowane w Kościołach partykularnych formy pobożności ludowej były traktowane jako komplementarne wobec liturgii. Mówiąc na ich temat, Katechizm Kościoła katolickiego przypomina soborową naukę: „Należy [je] tak uporządkować, aby zgadzały się z liturgią,

10 Por. DPLL, 11.

11 Por. DPLL, 74.

12 Por. Sobór Watykański II, Konstytucja Sacrosanctum concilium, 13.

13 Watykan: nowy dokument o pobożności ludowej (9.04.2002), https://ekai.pl/ watykan-nowy-dokument-o-poboznosci-ludowej/ (data dostępu: 17.02.2018). 
z niej poniekąd wypływały i do niej wiernych prowadziły, ponieważ ona ze swej natury znacznie je przewyższa" ${ }^{14}$.

Nabożeństwa ludowe stanowią cenną pomoc w przeżywaniu liturgii przez wiernych. Służą one usposobieniu ducha wierzących na przyjęcie łaski Bożej, jaka darowana jest uczestnikom liturgicznej celebracji tajemnicy Chrystusa ${ }^{15}$. Walorem pobożności ludowej jest to, że stanowi ona wyraz sposobu, w jaki wiara chrześcijańska wcieliła się w danej kulturze lokalnej i dalej jest w niej przekazywana; umożliwia socjalizację $\mathrm{w}$ wierze $^{16}$. Innymi słowy, pobożność ludowa jest spontanicznym wyrazem misyjnej działalności wierzących ${ }^{17}$. Paweł VI w adhortacji Evangelii nuntiandi do walorów pobożności ludowej zaliczył to, że ułatwia przeżywanie stałej obecności i dobroczynnej miłości Boga, a także wyrabia takie sprawności, jak cierpliwość, ofiarność i życzliwość dla innych ${ }^{18}$.

Gdy chodzi o ortodoksyjność liturgii i nabożeństw ludowych, nie ma różnicy między nimi, w tym sensie jakoby liturgia była wyrazem chrześcijańskiej doktryny, a nabożeństwa ludowe - nie. I jedna, i druga rzeczywistość zaliczana jest do miejsc teologicznych. „Kościół wierzy tak jak się modli” ${ }^{19}$. To znaczy, że oficjalne celebracje liturgiczne zaakceptowane przez Kościół są wyrazem jego wiary i jako takie stanowią „miejsce teologiczne” - stoją na straży wierności Bożemu Objawieniu. W tym znaczeniu liturgia jest obiektywnym wyrazem nauczania Kościoła i źródłem argumentów teologicznych służących uzasadnianiu twierdzeń dogmatycznych. Jest ona także kryterium służącym do weryfikacji teologicznej poprawności różnych form pobożności ludowej. Toteż zadaniem Nauczycielskiego Urzędu Kościoła, papieża i podległych mu kongregacji, jest czuwanie nad dogmatyczną poprawnością tekstów dopuszczanych do celebracji liturgicznych.

Podobnie należy wypowiedzieć się o zdrowej i usankcjonowanej przez kościelne władze pobożności ludowej. Jej różne przejawy zostały

${ }^{14}$ Sobór Watykański II, Konstytucja Sacrosanctum concilium, 13; KKK 1675.

${ }^{15}$ Por. S. Cichy, Pobożność ludowa, http://analizy.biz/apologetyka/index.phpoption=com_content\&task=view\&id=845\&Itemid=50.htm (data dostępu: 17.02.2018).

16 Por. Franciszek, Evangelii gaudium, 123.

17 Por. tamże, 122.

18 Por. Paweł VI, Evangelii nuntiandi, 48.

19 KKK 1124. 
zaliczone przez papieża Franciszka do „miejsc teologicznych”20. Ponadto Franciszek wymienił trzy istotne elementy pobożności ludowej: ewangeliczność, kościelność i misyjność ${ }^{1}$. Wcześniej Jorge Bergoglio wraz z biskupami z Ameryki Łacińskiej podkreślał w dokumencie z Aparecidy, że pobożność ludowa jest „pełnoprawnym sposobem przeżywania wiary, sposobem poczucia się częścią Kościoła”22. Nieco ostrożniejsze podejście do pobożności ludowej prezentował papież Paweł VI. Uznając jej walory, przestrzegał przed jej podatnością na wpływ fałszywych form religijnościi ${ }^{23}$.

Niezbędna jest więc troska duszpasterzy o to, by praktyki pobożne ludu Bożego były zgodne z prawdami wiary. Niekiedy dzieje się tak, że to właśnie pobożność ludowa pozwala lepiej zrozumieć prawdy wiary. Bywa też tak, że różne przejawy pobożności ludowej zostają z czasem włączone w liturgię. Wystarczy wspomnieć kult Najświętszego Serca Pana Jezusa, który miał swój początek w pobożności ludowej, a potem zyskał swój liturgiczny wyraz. Podobnie było z adoracją i kultem Najświętszego Sakramentu ${ }^{24}$ czy modlitwami za wiernych zmarłych.

Różne formy pobożności ludowej znakomicie harmonizują z przeżywanym przez Kościół rokiem liturgicznym. W tym także wyraża się komplementarność pobożności ludowej i liturgii ${ }^{25}$. Na przykład w czasie Adwentu i Bożego Narodzenia pobożność ludowa ukazuje wartość ludzkiego życia i potrzebę faktycznego wspierania matek ${ }^{26}$. Z kolei w okresie Wielkiego Postu skupia się na misterium człowieczeństwa Chrystusa, a zwłaszcza na Jego zbawczej męce i śmierci ${ }^{27}$. Pomimo sekularyzacji współczesnych społeczeństw, nabożeństwa ludowe pomagają wiernym właściwie oceniać przemijającą wartość dóbr doczesnych i potrzebę kiero-

${ }^{20}$ Franciszek, Evangelii gaudium, 126.

${ }^{21}$ Franciszek do bractw kościelnych o pobożności ludowej, http://www.opoka. org.pl/aktualnosci/news.php?id=47639\&s=opoka, Watykan, 05.05.2013 (data dostępu: 17.02.2018).

22 V Conferencia General del Episcopado Latinoamericano y del Caribe, Aparecida (13-31.05. 2007), nr 263-264.

${ }^{23}$ Paweł VI, Evangelii nuntiandi 48.

24 zob. KKK 1178.

25 Por. DPLL 94-182.

26 Por. DPLL 113.

27 Por. DPLL 124. 
wania pragnień ku wartościom nieprzemijającym. A ponieważ nie można ich osiągnąć inaczej, jak przez zgodność wyznawanej wiary z ewangelicznym zaangażowaniem, niezbędne jest wyrażanie wiary przez wyrzeczenie się tego, co zbyteczne i luksusowe oraz przez praktykowanie uczynków miłosierdzia wobec cierpiących i potrzebujących ${ }^{28}$.

Ze względu na swoje walory i komplementarność względem liturgii pobożność ludowa jest w Polsce szanowana i ceniona przez wiernych, hierarchię kościelną i teologów ${ }^{29}$. Szacunek okazywany różnym formom pobożności ludowej jest wyrazem zaufania Duchowi Świętemu, który działa w wieloraki sposób w Ludzie Bożym. Bardzo wyraźnie motyw ten doszedł do głosu w dokumencie biskupów latynoamerykańskich z Aparecidy ${ }^{30}$. A Dyrektorium o pobożności ludowej i liturgii zauważyło, że wszelkie dążenia eliminowania pobożności ludowej na rzecz „czystej liturgii” nie mają nic wspólnego z historyczną i eklezjalną rzeczywistością, wyrażają idealistyczne aspiracje i są nader często wyrazem inspirowanych ideologicznie uprzedzeń ${ }^{31}$.

Pokusą, jakiej należy unikać w praktyce duszpasterskiej, jest łączenie Mszy św. ze wszystkimi akcjami pastoralnymi. Już wiele lat temu A. J. Jungmann apelował, aby nie zastępować Mszą Świętą wielu praktykowanych nabożeństw. Uważał, iż taka praktyka jest wielkim zubożeniem życia Kościoła. Historia Kościoła potwierdza, że zawsze obok oficjalnej liturgii istniały różnorodne i bogate formy kontaktu z Bogiem ${ }^{32}$. Właściwe przeżycie Mszy św. możliwe jest dzięki uprzedzającej ją i następującej po niej głębokiej modlitwie osobistej, praktykowanym tradycyjnym formom pobożności ludowej i praktyce życia chrześcijańskiego.

${ }_{28}$ Por. DPLL 125; J. Przybyłowski, Duszpasterskie wyzwania, s. 153.

${ }_{29}$ Por. P. Taras, Religijność ludowa w Kościele katolickim, „Communio” 7 (1987) 6, s. 19; J. Przybyłowski, Duszpasterskie wyzwania, s. 145n.

30 Por. V Conferencia General del Episcopado Latinoamericano y del Caribe, Aparecida (13-31.05.2007), nr 264; J. Przybyłowski, Duszpasterskie wyzwania, s. 149.

31 DPLL 50.

32 B. Nadolski, Pobożność ludowa a liturgia, s. 96. 


\section{GŁOSZENIE SŁOWA BOŻEGO W LITURGIl I PODCZAS NABOŻEŃSTW LUDU BOŻEGO}

Istotnym elementem celebracji liturgicznej jest liturgia słowa, której integralnym elementem jest homilia. Gdy chodzi o nabożeństwa ludowe, nie są one w tak istotny sposób jak liturgia zintegrowane z proklamacją słowa Bożego i przepowiadaniem. Jednak w adhortacji Verbum Domini papież Benedykt XVI zauważył, że pobożność ludowa powinna czerpać wzór z liturgii słowa, a także podał motywację, dlaczego tak ważne jest głoszenie i słuchanie słowa Bożego podczas nabożeństw ludowych:

Co do różnych form pobożności ludowej, to chociaż nie są aktami liturgicznymi i nie należy ich mylić z celebracjami liturgii, dobrze jest, by na nich się wzorowały, a zwłaszcza by zawierały momenty przeznaczone na głoszenie i słuchanie słowa Bożego; istotnie, „w słowie biblijnym pobożność ludowa znajdzie niewyczerpane źródło natchnienia, niedościgłe wzorce modlitwy oraz owocne propozycje tematyczne" ${ }^{33}$.

Nieco dalej we wspomnianej adhortacji Benedykt XVI uzasadnił, że Słowo Boże stanowi podstawę autentycznej duchowości chrześcijańskiej, a wielka tradycja patrystyczna zalecała łączenie modlitwy z lekturą Pisma Świętego. Prawdziwa chrześcijańska pobożność znajduje bowiem wyraz w dialogu z Bogiem.

Jak mówi św. Augustyn: „Twoja modlitwa jest twoim słowem skierowanym do Boga. Kiedy czytasz [...], Bóg mówi do ciebie; kiedy się modlisz, to ty mówisz do Boga". Orygenes, jeden z mistrzów takiej lektury Biblii, uważa, „że zrozumienie Pism, bardziej niż studiowania, wymaga zażyłości z Chrystusem i modlitwy”. Jest on w istocie przekonany, że "najlepszą drogą do poznania Boga jest miłość oraz że nie ma autentycznej scientia Christi bez zakochania się w Nim"34.

${ }^{33}$ Benedykt XVI, Verbum Domini 65; DPLL (17.12.2001), 87; zob. H. Sławiński, Troska Kościoła o poprawę jakości homilii: od synodu o Eucharystii i Sacramentum Caritatis do synodu o stowie Bożym $i$ Verbum Domini, „Colloquia Theologica Ottoniana” 2012, nr 1, s. 37-62.

${ }^{34}$ Benedykt XVI, Verbum Domini 86. 
Można więc powiedzieć, że pobożność ludowa, która pragnie znaleźć się w nurcie wielkiej tradycji Kościoła powinna być przeniknięta słowem Bożym. Zadaniem duszpasterzy jest formowanie wiernych tak, aby swoją pobożność łączyli ze słuchaniem słowa Bożego i dążeniem do pełnienia woli Bożej.

\section{SPECYFIKA PRZEPOWIADANIA SŁOWA BOŻEGO PODCZAS NABOŻEŃSTW LUDU BOŻEGO}

Omówiona powyżej komplementarność liturgii i nabożeństw ludowych nie wyklucza ich odrębności i specyfiki. Należy dążyć do tego, by owe celebracje nie nakładały się na siebie w praktyce duszpasterskiej. Trzeba również unikać jakichkolwiek przejawów konkurowania nabożeństw ludowych z celebracjami liturgicznymi, a także przeciwstawiania ich sobie. Nabożeństwa nie powinny przybierać charakteru celebracji liturgicznych, ale zachowywać swój styl, prostotę i własny język ${ }^{35}$. Na specyfikę przepowiadania podczas nabożeństw ludu Bożego wpływa kontekst i podejście do słowa Bożego, a także podmiot oraz język.

\subsection{KONTEKST PRZEPOWIADANIA I PODEJŚCIE DO SŁOWA BOŻEGO PODCZAS NABOŻEŃSTW LUDU BOŻEGO}

Czymś istotnym dla przepowiadania słowa Bożego podczas nabożeństw ludu Bożego jest jego pozaliturgiczny kontekst. Ma on wpływ na rodzaj przepowiadania i podejście do słowa Bożego. Przepowiadanie podczas celebracji liturgicznych ma zawsze postać homilii, a podczas nabożeństw ludu Bożego ma postać kazania, co przypomniała Konferencja Episkopatu Polski we wskazaniach dotyczące homilii mszalnej ${ }^{36}$.

35 DPLL 13; J. Przybyłowski, Duszpasterskie wyzwania, s. 149.

36 Konferencji Episkopatu Polski. Komisja ds. Kultu Bożego i Dyscypliny Sakramentów, Wskazania Konferencji Episkopatu Polski dotyczące homilii mszalnej (21.11.2017), nr 7, http://episkopat.pl/biskupi-homilie-powinny-byc-kazdorazowostarannie-przygotowywane/ (data dostępu: 17.02.2018). 
Ze względu na swój integralny związek z liturgią homilia ma swoje źródło w celebrowanym misterium, zajmuje miejsce między liturgią słowa a obrzędem liturgicznym, a jej szczególną funkcją jest mistagogia. W związku z tym homilia ma specyficzną strukturę. Natomiast kazanie jako przepowiadanie dokonujące się poza liturgią nie jest poddane tym restrykcjom. Nie musi też spełniać funkcji mistagogicznej. Ma swobodniejszą strukturę i może bardziej niż homilia służyć funkcji dydaktycznej.

Kontekst decydujący o powyższym rozróżnieniu wpływa na specyfikę podejścia do słowa Bożego. Homilia jest proklamacją misterium Chrystusa na kanwie sprawowanych obrzędów liturgicznych, z którymi związane są określone czytania biblijne (por. KL 35). To znaczy, że głosiciel homilii musi zapoznać się z tekstami liturgicznymi i biblijnymi przypisanymi do sprawowania danych obrzędów. Niekiedy może dokonać wyboru spośród wyznaczonych czytań alternatywnych. Są one zawarte w Lekcjonarzu i księgach obrzędowych do sprawowania sakramentów i sakramentaliów. Również Liturgia godzin posiada wyznaczone teksty biblijne. Kontekst liturgiczny i dobrane do niego czytania są już swoistą hermeneutyką tekstów biblijnych, którą musi uwzględnić głosiciel homilii.

$\mathrm{Z}$ inną sytuacją mamy do czynienia podczas nabożeństw ludu Bożego. O specyfice przepowiadania podczas nabożeństw ludu Bożego nie decyduje związek ze słowem Bożym lub jego brak, ale sposób podejścia. Albowiem zgodnie z życzeniem ostatniego soboru słowo Boże powinno być podstawą wszelkiego przepowiadania kościelnego i refleksji teologicznej: „Tymże słowem Pisma św. żywi się również korzystnie i święcie się przez nie rozwija posługa słowa, czyli kaznodziejstwo, katecheza i wszelkie nauczanie chrześcijańskie, w którym homilia liturgiczna winna mieć szczególne miejsce" (KO 24).

Specyfika podejścia do słowa Bożego podczas nabożeństw ludowych polega na tym, że ten, kto podejmuje się przepowiadania w imieniu Kościoła może roztropnie dobrać sobie teksty biblijne. Podejmuje się wówczas wyjaśnienia ich w ich kontekście biblijnym oraz dokonania aktualizacji dobranego słowa Bożego dla słuchaczy ${ }^{37}$. Takie podejście do

37 Obszerne studium na temat aktualizacji słowa Bożego dostępne jest w znakomitym opracowaniu Jana Twardego, Aktualizacja słowa Bożego w kaznodziejstwie, Przemyśl 2009. 
Pisma Świętego wymaga jego dobrej znajomości, która pozwoli dobrać najlepsze fragmenty do rozwinięcia określonego tematu.

W rozwinięciu tematu pomaga klasyczna struktura kazania, na którą składają się wstęp, rozwinięcie i zakończenie. Inny model, który można z powodzeniem wykorzystać w kazaniu tematycznym głoszonym podczas nabożeństwa jest model dydaktyczny albo też dydaktyczno psychologiczny. Został on omówiony przez Heriberta Arensa w dziele Die Predigt als Lernprozess ${ }^{38}$. H. Arens rozumie kazanie jako odmianę procesu nauczania i uczenia się i uważa, że może być ono skuteczne o tyle tylko, o ile uwzględni prawa rządzące tym procesem, w którym niezbędne jest aktywne zaangażowanie słuchaczy. Trzeba oczywiście pamiętać o specyfice nabożeństwa, które służy w pierwszym rzędzie modlitwie, a dopiero wtórnie nauczaniu. Nauczanie dokonywane jest w służbie modlitwy i nabożeństwa. Owa drugorzędna funkcja nauczania skutkuje tym, że po nabożeństwie nie przeprowadza się kolokwium, jak po wykładzie. W tym ostatnim funkcja nauczania jest pierwszorzędna, toteż przyswojenie wiedzy przez słuchaczy podlega ewaluacji dokonywanej przez nauczyciela.

\subsection{PODMIOT PRZEPOWIADANIA PODCZAS NABOŻEŃSTW LUDU BOŻEGO}

Innym elementem specyficznym dla przepowiadania podczas nabożeństw ludowych jest podmiot posługi słowa. Przygotowana przez wiele dykasterii watykańskich instrukcja Ecclesiae de mysterio (1997) przypomniała, że głoszenie homilii podczas Mszy św. zastrzeżone jest osobie wyświęconej:

Nie jest bowiem istotne to, że ktoś posiada ewentualnie większą zdolność przemawiania lub zdobył lepsze przygotowanie teologiczne, ale fakt, iż funkcja ta jest zastrzeżona dla osoby, która otrzymała sakrament święceń, przez co nawet biskup diecezjalny nie ma prawa dyspensować od tego przepisu kanonicznego jako że nie jest to ustawa czysto dyscyplinarna, lecz dotycząca funkcji nauczania i uświęcania, ściśle ze sobą powiązanych ${ }^{39}$.

38 München 1972.

39 Kongregacja ds. Duchowieństwa i in., Instrukcja o niektórych aspektach 
Ten sam dokument zauważa, że wierni nie wyświęceni mogą głosić homilię poza Mszą św. w sposób zgodny z przepisami liturgicznymi ${ }^{40}$. Tym bardziej więc wierni świeccy mogą głosić słowo Boże podczas nabożeństw ludu Bożego, o ile tylko otrzymają do tego odpowiednie pozwolenie. Możliwość taka została dopuszczona w Kodeksie prawa kanonicznego z 1983 roku. Czytamy w nim: „Świeckich można dopuścić do przepowiadania w kościele lub kaplicy, jeśli w określonych okolicznościach domaga się tego konieczność albo gdy to w szczególnych wypadkach zaleca pożytek, zgodnie z przepisami wydanymi przez Konferencję Episkopatu i z zachowaniem przepisu kan. 767, $₫ 1$ "41. Wspomniany na końcu kanon rezerwuje homilię podczas Mszy św. dla osoby wyświęconej, o czym była wcześniej mowa. Tak więc nie tyle należy ograniczać możliwość głoszenia słowa Bożego przez wiernych świeckich, ale formować osoby, które będę chętne i dobrze przygotowywane do pełnienia tej szlachetnej posługi w Kościele. A najodpowiedniejszym kontekstem do takiej posługi są nabożeństwa ludu Bożego.

Papież Franciszek dostrzega i podkreśla potrzebę uaktywnienia wiernych świeckich w różnych wymiarach posługi kościelnej. Przemawiając w maju 2013 roku na placu św. Piotra do 70 tysięcy osób z różnych krajów świata, które przyjechały do Rzymu ze specjalną pielgrzymką dla członków bractw, papież Franciszek omawiał walory pobożności ludowej i zachęcał wiernych, by ją praktykowali, a przy tym zachęcał ich, by pielęgnowali tradycję bractw, które przez wieki były środowiskami sprzyjającymi rozwojowi świętości wielu ludzi. To właśnie dzięki przeżywanej wspólnie pobożności ludowej wiele osób doświadcza w swym życiu intensywnej relacji z Panem ${ }^{42}$.

dotyczących współpracy wiernych świeckich w ministerialne posłudze kapłanów, „Ecclesiae de mysterio" (15.08.1997), artykuł 3, §1.

${ }^{40}$ Por. tamże, artykuł 3, $\$ 4$.

${ }^{41}$ Kodeks prawa kanonicznego, Poznań 1983, kan. 766.

${ }^{42}$ Franciszek do bractw kościelnych o pobożności ludowej, http://www.opoka. org.pl/aktualnosci/news.php?id=47639\&s=opoka, Watykan, 05.05.2013 (data dostępu: 17.02.2018). 


\subsection{JĘZYK PRZEPOWIADANIA PODCZAS NABOŻEŃSTW LUDU BOŻEGO}

Mówiąc o Bogu należy zawsze zachować szacunek do Jego świętego imienia. Mówimy bowiem o kimś, kto góruje nad całym stworzeniem; jest Stwórcą i dobrym Ojcem, który pragnie zbawienia wszystkich ludzi. Bóg jest prawdą (J 14,6) i miłością (1 J 4,8), a „W nadmiarze swej miłości zwraca się do ludzi jak do przyjaciół (por. Wj 33,11; J 15,14-15)"43. Przykazanie Boże, by nie brać imienia Boga nadaremno jest krytyką paplania o $\mathrm{Bogu}^{44}$. A jednak trzeba o Nim mówić i głosić Jego plan, bo właśnie od głupstwa przepowiadania zależy wiara słuchaczy, będąca z kolei warunkiem przyjęcia zbawienia, jakie Bóg podarował ludziom w Chrystusie. „Bo sercem przyjęta wiara prowadzi do usprawiedliwienia, a wyznawanie jej ustami - do zbawienia. [...] Przeto wiara rodzi się z tego, co się słyszy, tym zaś, co się słyszy, jest słowo Chrystusa” (Rz 10, 10. 17).

Język przepowiadania podczas nabożeństw ludowych ma swój prawzór w języku biblijnym, bo wszelkie przepowiadanie Kościoła pozostaje zawsze na służbie słowa Bożego. Język biblijny najlepiej posłużył do wyrażenia treści natchnionych przez Ducha Świętego i to on nadal najlepiej służy do wyrażenia fundamentalnych wydarzeń chrześcijaństwa oraz różnych doświadczeń w relacji z Bogiem. Doświadczenia zaś najłatwiej wyraża się w opowiadaniu, za pomocą narracji. Dotyczy to także doświadczeń związanych ze zbawczymi interwencjami Boga i Objawieniem Bożym, na które człowiek odpowiada $\mathrm{z}$ wiarą. Ta zaś jest w swym pierwotnym znaczeniu odpowiedzią na słowo Boże, a dopiero w dalszym sensie przyjęciem doktryny. Przeżywane w wymiarze wiary doświadczenie ludzkie staje się treścią opowiadania i przepowiadania ${ }^{45}$.

Język przepowiadania podczas nabożeństw ludu Bożego może być o wiele swobodniejszy od języka homilii. Nie jest obwarowany licznymi normami. Dla uchwycenia różnicy, warto tu przytoczyć wypowiedź

${ }^{43}$ Sobór Watykański II, Konstytucja o Objawieniu Bożym. Dei Verbum, 2.

${ }_{44}$ Por. H. Sławiński, O możliwości i konieczności mówienia o Niewyrażalnym, „Studia Włocławskie”, t. 19 (2017), s. 319-332.

${ }^{45}$ Por. H. Sławiński, Problem języka $w$ nauczaniu religii wśród młodzieży, „Ateneum Kapłańskie” 626 (2013), z. 1, t. 161, s. 114; K. Misiaszek, Charakter języka katechezy, w: Język katechezy, red. R. Przybylska, W. Przyczyna, Tarnów 2008, s. 62 [52-69]. 
Kongregacji Kultu Bożego i Dyscypliny Sakramentów zawartą w „Piątej instrukcji dla poprawnego wprowadzenia konstytucji Soboru Watykańskiego Drugiego o liturgii świętej”, Liturgiam authenticam z 28 marca 2001 roku. Czytamy w niej, że

Słowa Pisma Świętego oraz inne słowa, wypowiadane w celebracjach liturgicznych, zwłaszcza przy sprawowaniu sakramentów, nie mają przede wszystkim stanowić odzwierciedlenia wewnętrznej dyspozycji wiernych, lecz wyrażają prawdy przekraczające granice czasu i miejsca. Poprzez te słowa [...] Duch Święty wprowadza chrześcijan we wszelką prawdę i sprawia, że Słowo Chrystusa mieszka w nich obficie, a Kościół utrwala i przekazuje wszystko, czym sam jest i w co wierzy ${ }^{46}$.

O ile przepowiadanie liturgiczne służy przede wszystkim wyrażeniu prawd przekraczających granice czasu i miejsca, o tyle przepowiadanie podczas nabożeństw ludowych może dać wyraz wewnętrznej dyspozycji wiernych. Przy czym nie może to oznaczać rezygnacji z ortodoksji na rzecz sentymentalizmu. Również przepowiadanie podczas nabożeństw ludowych musi być klarownym przekazem doktryny chrześcijańskiej, jakkolwiek jest w nim miejsce na jej swobodne i proste omówienie. Jasności, prostocie i zrozumiałości przez słuchaczy należy dać pierwszeństwo przed precyzją teologiczną. Ta jest niezbędna w orzeczeniach Urzędu Nauczycielskiego Kościoła i w traktatach teologicznych. Są one zazwyczaj wyrażone językiem hermetycznym, zrozumiałym dla specjalistów. Natomiast podczas nabożeństw ludowych prawdę zbawczą można i należy przybliżać wiernym za pomocą opowiadania, obrazów, poezji, metafor, symboli, analogii, a gdzie trzeba - również za pomocą niewyrafinowanej racjonalnej argumentacji.

Różnicę między precyzyjnym językiem naukowym a językiem stosowanym przez prostych ludzi i służącym do wywołania emocjonalnego przeżycia ilustruje ciekawe wydarzenie. Dnia 15 października 2005 roku w studio BBC w „Today Programme” spotkali się: pochodząca z Gruzji

${ }^{46}$ Kongregacja Kultu Bożego i Dyscypliny Sakramentów, Piąta instrukcja „dla poprawnego wprowadzenia konstytucji Soboru Watykańskiego Drugiego o liturgii świętej” (art. 36). Stosowanie języków narodowych przy wydawaniu ksiąg rzymskiej liturgii. Liturgiam authenticam (28 marca 2001), nr 19. 
piosenkarka angielska Ketevan „Katie” Melua (1984-) i matematyk Simon Lehna Singh (1964-), by rozmawiać na temat licencji artystycznej i naukowej precyzji. On zarzucał jej, że w swoim szlagierze pt. „Nine Million Bicycles” rozpowszechnia nieprawdę, śpiewając: „Jesteśmy 12 miliardów świetlnych lat od krańca. To tylko domysł - nikt nie powie, że to fakt, ale wiem, że zawsze będę z tobą". W odpowiedzi na zarzuty matematyka, Katie Melua zaśpiewała tekst proponowany przez naukowca: „Jesteśmy 13,7 miliardów lat świetlnych od krańca obserwowanego wszechświata; to słuszne stwierdzenie $\mathrm{z}$ wyraźnie określoną granicą błędu, na podstawie dostępnych informacji, zapowiadam, że zawsze będę z tobą". Obie strony przyznały, że w nowej, poprawnej naukowo wersji, szlagier nie miałby większych szans na komercyjny sukces ${ }^{47}$.

Podobnie jak ,jest czas rodzenia i czas umierania, czas sadzenia i czas wyrywania tego, co zasadzono" (Koh 3, 2), tak też jest czas stosowania precyzyjnego języka naukowego i czas języka artystycznego. Nabożeństwo ludowe pozwala odwołać się do języka stosowanego przez artystów, bliskiego egzystencjalnemu doświadczeniu słuchaczy.

Język przepowiadania podczas nabożeństw musi być przeniknięty z jednej strony szacunkiem do różnych form pobożności oraz do słuchaczy i ich wolności, a z drugiej strony krytycznym stosunkiem do tego wszystkiego, co wyraźnie sprzeciwia się religijności chrześcijańskiej. Przykładem braku szacunku dla wolności wiernych, jak zauważa jeden z teologów, jest nazywanie zabaw sylwestrowych „bezmyślną rozpustą świeckiej społeczności”. Taki język „przekreśla możliwość dialogu kulturowego nawet z ludźmi wierzącymi, którzy są uczestnikami takich zabaw"48. Kaznodzieja może preferować spędzenie wieczoru sylwestrowego na modlitwie, ale nie oznacza to, że wszyscy wierni mają być zobowiązani do praktyk religijnych promowanych przez duszpasterza. Trzeba uszanować wolność wiernych i uczciwie rozróżniać przedsięwzięcia duszpasterskie, które są dla wiernych obligatoryjne oraz te, które są fakultatywne. Jeśli we wspomnianym przykładzie wierni zechcą, zorganizują spotkanie syl-

47 Zob. H. Sławiński, Wkład papieża Franciszka w język nowej ewangelizacji, w: Nowa ewangelizacja. Język - teologia - kultura, red. M. Nowak, W Przyczyna (Teolingwistyka 13), Tarnów 2017, s. 231-255.

48 J. Przybyłowski, Duszpasterskie wyzwania, s. 151. 
westrowe połączone $\mathrm{z}$ modlitwą. Wierni uczynią to, co sami uznają za dobre i właściwe dla siebie, a postawa duszpasterza jest jego autoprezentacją świadczącą o stosunku do wiernych. Lepiej jest więc posługiwać się językiem, który respektuje wolność słuchaczy, również w zakresie form pobożności ludowej aniżeli językiem obcesowym i autorytarnym.

Krytyczne podejście głosiciela słowa jest natomiast niezbędne wobec wypaczeń religijności, gdy ociera się ona o magię, spirytyzm, zabobony, fatalizm czy aroganckie odnoszenie się do innych. Napiętnowania domagają się także spektakularne gesty i zachowania religijne ${ }^{49}$. Pobożność ludowa domaga się korygowania. A wśród niebezpieczeństw, jakie jej zagrażają, wymienia się:

niewystarczająca znajomość takich podstawowych zasad wiary chrześcijańskiej, jak zbawcze znaczenie zmartwychwstania Chrystusa, znaczenie przynależności do Kościoła, osoba i działanie Ducha Świętego; brak odpowiednich proporcji między kultem świętych i świadomością bezwzględnej wyższości roli tajemnicy Jezusa Chrystusa; słaby kontakt z Pismem Świętym; brak korzystania ze świętych sakramentów Kościoła; tendencja do oddzielania przeżyć kultycznych od zaangażowania w życie chrześcijańskie; utylitarystyczne rozumienie różnych form pobożności ${ }^{50}$.

Konstruktywna autokrytyka może pomóc w oczyszczeniu pobożności ludowej i ukazaniu jej łączności z liturgią i całą ewangelizacyjną, i duszpasterską działalnością Kościoła.

\section{ZAKOŃCZENIE}

Duchowe życie wiernych i cała działalność Kościoła nie ogranicza się jedynie do celebracji liturgicznych (por. KL 12), ale obejmuje także różnorodne formy pobożności ludowej. Choć przepowiadanie słowa Bożego nie jest związane z pobożnością ludową tak ściśle jak z liturgią, niemniej może i powinno jej towarzyszyć, wzbogacać ją i oczyszczać z tego, co jest nie do pogodzenia ze zdrową duchowością chrześcijańską. Istnieją

\footnotetext{
49 DPLL 65.

50 J. Przybyłowski, Duszpasterskie wyzwania, s. 146.
} 
w Polsce formy pobożności ludowej, w których przepowiadanie słowa Bożego jest uświęcone wielowiekową tradycją. Wystarczy wspomnieć przede wszystkim Gorzkie żale, nabożeństwa majowe i nabożeństwa różańcowe. Do ze wszech miar godnych polecenia form przepowiadania podczas nabożeństw ludowych należą kazania rekolekcyjne połączone z celebracją słowa Bożego czy też innymi nabożeństwami. Tym, co domaga się większej promocji w Kościele w Polsce, jest zaangażowanie do posługi słowa podczas nabożeństw ludowych dobrze uformowanych wiernych świeckich.

\section{BIBLIOGRAFIA}

\section{Źródła}

Benedykt XVI, Adhortacja apostolska Verbum Domini (30.09.2010), AAS 102 (2010), s. $681-787$.

Franciszek, Evangelii gaudium (24.11.2013), AAS (2013), s. 1019-1137.

Katechizm Kościoła Katolickiego, Poznań 1994.

Kodeks prawa kanonicznego, Poznań 1983.

Konferencji Episkopatu Polski. Komisja ds. Kultu Bożego i Dyscypliny Sakramentów, Wskazania Konferencji Episkopatu Polski dotyczace homilii mszalnej (21.11.2017), http://episkopat.pl/biskupi-homilie-powinny-byc-kazdorazowo-starannieprzygotowywane/ (data dostępu: 17.02.2018).

Kongregacja ds. Duchowieństwa, Papieska Rada ds. Świeckich, Kongregacja Nauki Wiary, Kongregacja ds. Kultu Bożego i Dyscypliny Sakramentów, Kongregacja ds. Biskupów, Kongregacja ds. Ewangelizacji Narodów, Kongregacja ds. Instytutów Życia Konsekrowanego i Stowarzyszeń Życia Apostolskiego, Papieska Rada ds. Interpretacji Tekstów Prawnych, Instrukcja o niektórych aspektach dotyczacych wspótpracy wiernych świeckich $w$ ministerialne posłudze kapłanów, „Ecclesiae de mysterio” (15.08.1997), AAS 89 (1997), s. 852-877, tekst polski, „L'Osservatore Romano", wyd. pol., 12 (1998), s. 30-40.

Kongregacja ds. Kultu Bożego i Dyscypliny Sakramentów, Dyrektorium o pobożności ludowej i liturgii, Zasady i wskazania (17.12.2001), Poznań 2003.

Kongregacja Kultu Bożego i Dyscypliny Sakramentów, Piąta instrukcja „dla poprawnego wprowadzenia konstytucji Soboru Watykańskiego Drugiego o liturgii świętej” (art. 36). Stosowanie języków narodowych przy wydawaniu ksiąg rzymskiej liturgii. Liturgiam authenticam (28.03.2001), „Notitiae” 37 (2001), s. 120 -174 .

Paweł VI, Adhortacja apostolska Evangelii nuntiandi (8.12.1975), AAS 68 (1976), s. 5-76. Sobór Watykański II, Konstytucja dogmatyczna o Objawieniu Bożym, Dei Verbum (18.11.1965). 
Sobór Watykański II, Konstytucja o liturgii świętej, Sacrosanctum Concilium (4.12.1963). V Conferencia General del Episcopado Latinoamericano y del Caribe, Documento de Aparecida (13-31.05.2007), Aparecida 2007.

\section{Literatura przedmiotu}

Arens H. Die Predigt als Lernprozess, München 1972.

Brzeziński D., Sakramentalność słowa Bożego w świetle adhortacji apostolskiej Benedykta XVI, Verbum Domini, „Liturgia Sacra” 17 (2011), nr 1, s. 15-23.

Cichy S. bp, Pobożność ludowa, http://analizy.biz/apologetyka/index.php-option=com_ content\&task=view\&id=845\&Itemid=50.htm (data dostępu: 17.02.2018).

Franciszek do bractw kościelnych o pobożności ludowej, http://www.opoka.org.pl/aktualnosci/news.php?id=47639\&s=opoka, Watykan, 05.05.2013 (data dostępu: 17.02.2018).

Misiaszek K., Charakter języka katechezy, w: Język katechezy, red. R. Przybylska, W. Przyczyna, Tarnów 2008, s. 52-69.

Nadolski B., Leksykon liturgii, Pallottinum, Poznań 2006.

Nadolski B., Pobożność ludowa a liturgia, „Communio” 7 (1987) 6, s. 91-106.

O’Collins G., Farrugia E.G., Leksykon pojęć teologicznych i kościelnych z indeksem angielsko-polskim, Wydawnictwo WAM, Kraków 2002.

Przybyłowski J., Duszpasterskie wyzwania Dyrektorium o pobożności ludowej i liturgii, „Seminare” 20 (2004), s. 145-162.

Sławiński H., O możliwości i konieczności mówienia o Niewyrażalnym, „Studia Włocławskie", t. 19 (2017), s. 319-332.

Sławiński H., Problem języka w nauczaniu religii wśród młodzieży, „Ateneum Kapłańskie” 626 (2013), z. 1, t. 161, s. 109-128.

Sławiński H., Troska Kościoła o poprawe jakości homilii: od synodu o Eucharystii i Sacramentum Caritatis do synodu o słowie Bożym i Verbum Domini, „Colloquia Theologica Ottoniana" 2012, nr 1, s. 37-62.

Sławiński H., Wkład papieża Franciszka w język nowej ewangelizacji, w: Nowa ewangelizacja. Język - teologia - kultura, red. M. Nowak, W Przyczyna (Teolingwistyka 13), Tarnów 2017, s. 231-255.

Taras P., Religijność ludowa w Kościele katolickim, „Communio” 7 (1987) 6, s. 14-19.

Twardy J., Aktualizacja słowa Bożego w kaznodziejstwie, Przemyśl 2009

Watykan: nowy dokument o pobożności ludowej (9.04.2002), https://ekai.pl/watykan-nowy-dokument-o-poboznosci-ludowej/ (data dostępu: 17.02.2018). 